\title{
Sosyal Politika Açısından Kayıt Dışı Ekonominin Önemi
}

\section{The Importance of the Informal Economy for Social Policy}

\author{
Sefa KARAGÖZ1 ${ }^{10}$
}

\section{Öz}

Kayıt dışı ekonomi hem ekonomik hem de sosyal etkileri olan çok yönlü bir olgudur. Kayıt dışı ekonominin işsizlik, gelir dağılımı, yoksulluk ve göç ile ilişkili olması sosyal politika bağlamında bir inceleme yapılmasının önemini ortaya koymaktadır. Bu çalışma da buradan hareketle sosyal politikanın temel uğraş alanı olan konularla kayıt dışı ekonominin ilişkisi üzerinden bir çıkarım yapma amacı gütmektedir. Çalışmada sosyal politikanın temel uğraş alanlarından olan işsizlik, gelir dağılımı-yoksulluk, göç ve kayıt dışı istihdam bağlamında yapılan çeşitli ampirik çalışmalardan yararlanılarak sosyal politikalar yapılırken kayıt dışı ekonominin önemli olup olmadığı tartışılmıştır. Çalışmanın sonucunda ise kayıt dışı ekonominin işsizlik, gelir dağılımıyoksulluk ve göç ile olan ilişkisinde hem olumlu hem de olumsuz etkilerinin olduğu tespit edilmiş ve sosyal politikalar yapılırken mevcut sosyal sorunun daha da derinleşmemesi adına kayıt dışı ekonominin dikkate alınmasının gerekliliği vurgulanmıştır.

Anahtar kelimeler: Sosyal politika, Kayıt dışı ekonomi, Kayıt dışı istihdam

JEL Sınıflaması: E24, E26

\section{ABSTRACT}

The informal economy is a multifaceted phenomenon with both economic and social consequences. It is important to better understand the informal economy in the context of social policy, as the informal sector is also associated with unemployment, income distribution, poverty, and migration. Thus, this study aims to draw conclusions about the relationship between the informal economy and outcomes in the primary areas of social policy. Accordingly, an evaluation was made in the context of unemployment, income distribution-poverty, migration, and informal employment, with the objective of revealing the relationship between the informal economy and

1Doktora Öğrencisi, İstanbul Üniversitesi, Sosyal Bilimler Enstitüsü, Çalışma Ekonomisi ve Endüstri Illişkileri Anabilim Dalı, İstanbul, Türkiye

ORCID: S.K. 0000-0002-0628-2980

Sorumlu yazar/Corresponding author: Sefa KARAGÖZ,

İstanbul Üniversitesi, Sosyal Bilimler Enstitüsü, Çalışma Ekonomisi ve Endüstri Ilişkileri Ana Bilim Dalı, İstanbul, Türkiye

E-posta/E-mail: sefakaragoz@ogr.iu.edu.tr

Başvuru/Submitted: 19.11.2020 Revizyon Talebi/Revision Requested: 28.11.2020

Son Revizyon/Last Revision Received:

03.12.2020

Kabul/Accepted: 03.12.2020

Atıf/Citation: Karagoz, S. (2020). Sosyal politika açısından kayıt dışı ekonominin önemi. İstanbul iktisat Dergisi - Istanbul Journal of Economics, $70(2), 481-507$.

https://doi.org/10.26650/ISTJECON2020-828581 
social policy. The analysis of these relationships is based largely on empirical studies in the literature. It was found that the informal economy has both positive and negative consequences for unemployment, income distribution-poverty, and migration and that the informal economy must be considered in social policy planning so as to avoid deepening current social problems.

Keywords: Social policy, Informal economy, Informal employment

JEL Classification: E24, E26

\section{EXTENDED ABSTRACT}

Although social policy is defined in various ways in the literature, it can be broadly identified as policies that address and seek to find solutions to the problems of society. Social policy is designed and implemented by multiple actors, the most powerful of which is the state. Some studies argue that the state is the primary actor in social policy and that other stakeholders are only complementary actors. From this point of view, it is possible to argue that the social policy-state relationship is generally shaped around the concept of the welfare state.

The informal economy began to attract attention globally starting in the 1960s and since then has been the subject of various studies. The informal economy has not only emerged for reasons that vary across countries, societies, and regions, but it also has both positive and negative consequences. The informal sector can affect state revenues due to its close ties with the formal economy, and its size is important for economic policies as well as other policies of the state.

Like all public policy, social policies are financed from the central government's general budget. Thus taxes, which represent the largest source of income of the state, are key in terms of social policy. In turn, the size of the informal economy is directly or indirectly related to social policies.

This study examines the relationship between the informal economy and social policy, two leading subjects in the social science literature. The impact of the informal economy on social policy formulation was explored by considering various empirical studies on the informal economy in the context of the main areas 
of social policy including unemployment, income distribution-poverty, immigration, and unregistered employment.

Existing studies of the relationship between unemployment and the informal economy have revealed that the unofficial sector has both positive and negative consequences for unemployment. While the negative consequences generally emerge in terms of constraints on social rights, a decrease in unemployment rates in the short term can be considered a positive outcome. Some studies have concluded that this relationship is uncertain; however, in studies examining the relationship between income distribution and poverty with the informal economy, it is generally found that the informal economy negatively affects income distribution equality in the long-term and results in increased poverty levels. Studies on the relationship between immigration and the informal economy have concluded that the informal economy is both a cause and a result of immigration. In other words, the fact that immigrants tend to work in the informal sector, where jobs can be found more quickly to generate income or to adapt to a new city, is considered one of the primary drivers of the informal economy. Cross-border immigration of people to countries with more labor opportunities to find jobs in the informal sector is also one of the consequences of the informal economy. Unregistered employment, considered one of the most important fields of activity of the informal economy, is a reflection of the informal economy on labor markets.

It is clear that the informal economy has both positive and negative effects on the most fundamental areas of social policy. It is thus crucial to consider the dynamics of the informal social when developing social policies to avoid aggravating current social problems. Whether it is more beneficial to shrink the informal economy or to produce direct solutions to social problems may vary depending on the particular socio-economic conditions of each country. 


\section{Giriş}

Sosyal politika, sanayi devriminden önceki dönemlerde 'geleneksel sosyal politika' olarak adlandırılan aile, din ve yardımlaşma gibi mefhumların ekseninde şekillenen bir olgu iken; sanayi devrimi sonrasında 'modern sosyal politika' olarak nitelendirilmiş ve devletin sosyal politika içerisindeki yeri belirginleşmiştir. Sosyal politikanın birden fazla aktörü bulunmakla birlikte devletin bu aktörler arasındaki yeri oldukça önemlidir. Devletin aktörler arasındaki bu önemli yerini anlamak adına diğer aktörlerin devletin rolünü tamamlayıcı bir görev üstlendiklerini ifade etmek yanlış olmayacaktır.

Kayıt dışı ekonomi ise devletler açısından önemli bir sorun olarak görülmekle birlikte, kimi araştırmacılar tarafından hem olumlu ve olumsuz etkileri olduğu ifade edilmektedir. Fakat uzun dönemde olumsuz etkilerinin olumlu etkileri bertaraf edeceği ve dolayısıyla olumsuz etkilerinin daha fazla ciddiye alınması gerektiği literatürdeki hâkim görüştür. Kayıt dışı ekonominin birden fazla nedeni olmakla birlikte çok boyutlu birden fazla sonucu-etkisi de bulunmaktadır. Bu etkiler genel olarak ekonomik ve sosyal sorunlara sebep olan meselelerden oluşmaktadır. Şöyle ki olumsuz etkiler hem devletin ekonomi ve sosyal politikalarını etkilerken hem de vatandaşı (bireyi) hak kayıpları başta olmak üzere çeşitli yönlerden etkilemektedir. Bu çalışmada sosyal politika açısından kayıt dışı ekonominin önemi tartışılmış ve bu tartışma yapııırken sosyal politikanın en temel ilgi alanları olan işsizlik, gelir dağılımıyoksulluk, göç ve kayıt dışı istihdam konularında yapılmış ampirik çalışmalardan yararlanılmıştır. Çalışmanın amacı literatürde kayıt dışı ekonominin sosyal etkilerini inceleyen çalışmalar olsa da genel anlamda sosyal politika bağlamında kayıt dışı ekonominin önemine değinen çalışmaların çok az olması nedeniyle bu eksiğe dikkat çekme ve eksikliğin giderilmesine katkı sağlama çabasıdır. Bunun yanında çalışmanın asıl ve en önemli amacı ise, kayıt dışı ekonomi ve sosyal politika ilişkisini ortaya koymaktır.

Çalışma üç bölümden oluşmaktadır. Çalışmanın birinci bölümünde sosyal politika konusu genel hatlarıyla incelenmiş, ikinci bölümde de kayıt dışı ekonomi konusu genel hatlarıyla ele alınmıştır. Çalışmanın son bölümünde ise işsizlik, gelir dağılımıyoksulluk, göç ve kayıt dışı istihdam ile kayıt dışı ekonomi arasındaki ilişkiyi inceleyen 
çeşitli çalışmalardan yararlanılarak kayıt dışı ekonomi ve sosyal politika arasındaki ilişkiye dikkat çekilmiştir. Çalışmanın sonucunda ise kayıt dışı ekonominin sosyal politikalar yapılırken önemli olduğu vurgulanmıştır. Ayrıca sosyal politikalar yapılırken kayıt dışı ekonominin göz ardı edilmesinin mevcut sosyal sorunları derinleştirerek devletlere daha büyük yük olabileceği vurgulanmıştır.

\section{Genel Hatlarıyla Sosyal Politika}

Tarihsel süreç içerisinde işleyişi ile var olan sosyal politika, sanayi devrimi ile modern bir kavram olarak varlığını devam ettirmiştir (Taşçı, 2017, s. 13). Sosyal politika kavramı literatürde genel olarak dar ve geniş anlamda olmak üzere iki şekilde tanımlanmaktadır. Dar anlamda sosyal politika, kavramın ilk ortaya çıkış amacı doğrultusunda yalnızca çalışma hayatı içerisinde ortaya çıkan sorunların çözümüne yönelik politikalar olarak ifade edilmektedir. Talas'a göre, devletin politikalarının sadece belirli kitlelere yönelik olması söz konusuysa, bu dar anlamda sosyal politikadır (Talas, 1992, s. 15). Bunun yanında geniş anlamda sosyal politika ise, sadece çalışma hayatı değil toplumu ilgilendiren bütün meseleleri de kapsamına alan politikalar olarak tanımlanmaktadır. Geniş anlamda sosyal politika sınıf farkı gözetmeksizin toplumu bir bütün olarak ele almaktadır (Talas, 1992, s. 16).

Sosyal politikanın kapsamına girebilecek konuları genel olarak şu şekilde sıralamak mümkündür: beşeri ilişkiler, personel yönetimi, toplu pazarlık sistemi, sendikacılık, istihdam, maaş ve ücretler (Tuna ve Yalçıntaş, 2011, s. 31), işsizlik, gelir dağılımı, yoksulluk, sosyal güvenlik(sosyal sigortalar, sosyal hizmetler, sosyal yardımlar), sosyal dışlanma, sosyal diyalog, çevre, göç ve diğer dezavantajlı grupların sorunları.

Sosyal politikanın aktörleri ise, sivil kesim (aile, akrabalık, komşuluk), din (zekat gibi yardımlaşmaya dönük dini vecibeler), piyasa (özel sektör), gönüllü sektör (sivil toplum kuruluşları) ve devlettir (merkezi ve yerel yönetimler) (Ersöz, 2004, s. 12-22).

Sosyal politika tarihi genel olarak sosyal politikada devletin aktör olarak varlığına göre dönemlere ayrılmaktadır. Devletin önemli bir güç olarak sosyal 
politikalarda yer almaması geleneksel dönem veya hayırseverlik dönemi şeklinde ifade edilmektedir. Bu dönemlerde daha çok yukarıda sayılan sivil kesim ve din sosyal politikalarda önemli rol oynamaktadır. Devletin sosyal politikalarda merkez olması ise İngiltere'de bazı yasaların çıkmasıyla gerçekleşmiştir (1601 Yoksulluk Yasası gibi) (Akbaş, 2019, s. 15). Devletin sosyal politikalarda etkin olduğu durum refah devleti veya sosyal devlet şeklinde ifade edilmektedir.

Daha önce de bahsedildiği üzere sosyal politikanın birden fazla aktörü bulunmaktadır. Fakat sosyal politikalarda devletin rolünün ne kadar büyük olduğunun anlaşılması adına devletin uygulayıcısı olduğu sosyal politikaların, uygulayıcısı olmadığı sosyal politikalara göre daha etkin olduğu ifade edilebilir. Sosyal politika önlemlerinin ve düzenlemelerinin devletin yasal sorumluluk alanında olduğunu belirtmek de devletin rolünün anlaşılması bakımından doğru olacaktır (Önal, 2017, s. 12).

Devletlerin ekonomik güçleri doğrultusunda sosyal politikalarda etkin olabildiklerini ifade etmek yanlış olmayacaktır. Özdemir'in de belirttiği gibi ekonomik yönden güçlü olmayan devletler vatandaşlarına gerektiği ölçüde refah sağlayamamakta ve bir yandan sosyal adaleti sağlamaya çalışırken diğer yanda hızlı kalkınma hedefine ulaşmaya çaba göstermektedir. Dolayısıyla ekonomi politikaları ile sosyal politikalar arasında büyük bir ilişki olduğu vurgulanmalıdır (Özdemir, 2007, s. 25). Buradan hareketle aşağıda daha detaylı ele alınmak sureti ile, kayıt dışı ekonominin, ülkelerin ekonomilerini olumlu veya olumsuz yönde etkilemeleri göz önüne alındığında sosyal politika açısından da önemli bir husus olduğunu ifade etmek mümkündür.

Devlet tarafından yapılan sosyal politikaların finansmanı büyük oranda kamu kaynaklarından sağlanmaktadır. Kamu bütçesinin en büyük gelir kaynağı ise vergilerdir. Dolayısıyla devletin diğer politikaları gibi sosyal politikalarının finansmanının da toplum tarafından sağlandığı ifade edilebilir. Devlet burada düzenleyici ve denetleyici rol oynayarak, vergilerin toplanması ve harcanmasında yetkilidir. 
Sosyal politika ve vergi hususu genel olarak üç yönden ilişkilendirilebilir. Illki, daha önce de bahsedildiği üzere, vergilerin temel kamu finansman aracı olmasıdır. İkincisi, devletin vergileri bir müdahale aracı olarak kullanması ve vergi sorumluluğunun hafifletilmesi veya tamamen ortadan kaldırılması gibi ayırıcı sosyal politika işlevleri yüklenmesidir. Üçüncüsü ise, vergilerin sosyal politika amacına uygun şekilde toplanmaması sonucu, daha düşük gelirlilerden daha fazla vergi alınmasına bağlı olarak onların daha fazla yoksullaşması gibi olumsuz sonuçların ortaya çıkmasıdır (Karabacak, 2013, s. 247-248).

Sosyal politikanın finansmanında vergilerin önemi şu ifadelerle çok daha net anlaşılabilir:

"Ölümü dikkate almaksızın yaşamı anlamak ne kadar imkansız ise vergilemeyi dikkate almaksızın sosyal harcamalar aracılı̆ıyla gerçekleştirilen yeniden dağılımı anlamak da o kadar imkansızdır (Amenta, 1998, s. 948'den aktaran Nacar Karabacak, 2013, s. 148)".

Kayıt dışı ekonomi çok farklı şekillerde tanımlanırken genelde vergiler üzerinden hareket edilmektedir ${ }^{1}$. Dolayısıyla kayıt dışı ekonomi ve sosyal politika arasında çok yönlü ve kuvvetli bir ilişkinin var olduğu ifade edilebilir. Gelir dağılımından yoksulluğa, işsizlikten göçe kadar sosyal politikanın temel konusu olan meseleler üçüncü bölümde daha açık ve ayrıntılı anlatılacağı üzere kayıt dışı ekonomiyle de yakından ilgilidir.

\section{Genel Hatlarıyla Kayıt Dışı Ekonomi}

Kayıt dışı ekonomi kavramı, son yıllarda tüm dünyada ilgi gören konular arasında önemli bir yere sahiptir. Gelişme düzeyi fark etmeksizin hemen hemen bütün ülkelerde rastlanan, yoğun araştırmalar yapılmasına neden olan, uluslararası kuruluşlarında ilgisini çeken ve bu konuda raporlar hazırlanmasına sebep olan fakat bir türlü çözülemeyen bir sorundur. Türkiye'de de 2008 yılı kayıt dışı

\footnotetext{
1 Vergi kayıp ve kaçaklarının kayıt dışı ekonomi ile ilgisinin olmadığı yönünde ampirik çalışmalar da mevcuttur. Bkz. Elgin, 2012
} 
ekonomi ile mücadele yılı olarak ilan edilmiş, 8. Beş Yıllık Kalkınma Planı'nda özel ihtisas komisyonu kurulmuş (Kırbaş, 2012, s. 17) ve bu komisyon kayıt dışı ekonomi ile mücadeleye yönelik bir rapor hazırlamıştır.

Kayıt dışı ekonomi, bir çeşit resmi olmayan ekonomidir. Fakat literatürde kavramın tanımlanması hususunda fikir birliği yoktur. Kayıt dışı ekonomi, bir anlamda görünmeyen için teori arayışında bir ön kavramdır. Tanımlardaki farklılıklar, kayıt dışı ekonomi araştırmalarının kayıt dışı ekonominin büyüklüğünü hesaplamak veya kayıt dışı ekonominin sebeplerini araştırmak gibi hedeflerinin farklı olmasından kaynaklanmaktadır. Genel olarak kayıt dışı ekonomiyi açıklamak üzere iki yaklaşım vardır. Bunlar, tanımlayıcı yaklaşım ve davranışsal yaklaşımdır. Tanımlayıcı yaklaşım, kayıt dışı ekonomiyi tanımlarken yalnızca kayıt alına alınmayan ekonomik faaliyetleri göz önüne almakta, davranışsal yaklaşım ise ekonomik faaliyetlerdeki davranışsal özellikleri dikkate almaktadır. Bu yaklaşımlardan ilki yalnızca bir tanım yapmak amacını güderken, ikincisi yani davranışsal yaklaşım kayıt dışı ekonomik faaliyetleri açıklamak için teorik bir temel oluşturma gayretindedir (Fleming, Roman ve Farrell, 2000, s. 389).

Literatürde yaygın olarak kullanılan tanıma göre kayıt dışı ekonomi, eğer kayıtlı olsaydı Gayri Safi Yurt İçi Hasıla (GSYIH)'ya yansıyacak olan fakat kayıt altına alınmamış olan ekonomik faaliyetlerin tümüdür (Schneider, 2016, s. 44). Bir başka tanıma göre ise kayıt dışı ekonomi, piyasada üretilen yasal veya yasal olmayan mal ve hizmetlerin GSYIH tahminlerine yansımamasıdır (Smith, 1994, s. 18). Yukarıdaki tanımlara göre nispeten daha geniş bir anlam içeren kayıt dışı ekonomi tanımı ise, ekonomik faaliyetlerin veya elde edilen gelirlerin devletin vergilendirme kurallarına göre olmaması veya denetimleri atlatmış olmaları şeklinde ifade edilmektedir (Schneider, 2016, s. 44).

Kayıt dışı ekonominin ortaya çıkmasındaki en temel neden, insan ihtiyaçlarının sonsuz olması ve kaynakların kısıtlı olmasıdır. Birey, daha iyi bir hayat yaşayabilmek adına daha fazla gelir ve servete sahip olmak ve bu minvalde daha fazla harcama yapabilmek için gelirini devletle paylaşmak istemez. Dolayısıyla kayıt dışı ekonomide faaliyet gösteren birey, alışıı̆ı tüketim düzeyinde kalmak istediği için kayıtlı ekonomiye 
geçerek vergi gibi mali yükümlülüklerini yerine getirmek istememektedir. Buna bağlı olarak kayıt dışı ekonominin temel çıkış noktasını bireylerin faydalarını maksimize etme düşüncesi olarak ifade etmek mümkündür (Bozkurt, 2014, s. 45). Literatürde kayıt dışı ekonominin nedenleri genel olarak beş kategoride incelenmektedir. Bunlar sırasıly mali ve ekonomik nedenler, hukuki ve idari nedenler, sosyal ve psikolojik nedenler, siyasi nedenler ve yapısal nedenlerdir. Bu kategorilerin altında çok çeşitli unsurlar yer almakla birlikte en geniş kategori mali ve ekonomik nedenler kategorisidir.

Kayıt dışı ekonomi kaçınılmaz olarak dünyadaki kayıtlı ekonomilere eşlik eden çok boyutlu ve çok yönlü bir olgudur. Özellikleri ve boyutları çok farklı olabilir. Buna göre, uzun dönemde ekonomik büyüme üzerinde çok olumsuz bir etki bırakabileceği gibi, bazı ekonomilerde olumlu sonuçlar da doğurabilmektedir. Kayıt dışı ekonomi, bulunduğu ülkelerde her ne kadar olumlu etki gösterse de genel olarak ekonomide, yasal düzenlemelerde ve kurumsal yapıda olumsuz etkisi daha derin olmaktadır (Arandarenko, 2015, s. 5).

Önder'e (2001, s. 246) göre kayıt dışı ekonominin olumlu etkileri, kayıt dışı ekonominin kuralsı çalışması halinde yaratılan gelirlerle ölçülemez. Küçük oranlarda gerçekleşen mutlak zenginleşme ile diğer ülkelere göre geri kalmak olumlu değil olumsuz olarak görülmelidir. Ayrıca kayıt dışı ekonominin sadece kısa dönemde olumlu etkilerinin olacağı ve hem kısa dönemde hem de uzun dönemde kayıtlı ekonomi üzerinde pek çok olumsuz etkisinin olacağı ifade edilmelidir (Us, 2005, s. 98).

\section{Kayıt Dışı Ekonomi ve Sosyal Politika Iilişkisi}

Kayıt dışı ekonomi ve sosyal politika ilişkisi; sosyal politikanın temel uğraş alanlarından işsizlik, gelir dağılımı-yoksulluk, göç ve kayıt dışı istihdam konularında yapılmış ampirik çalısmalar üzerinden incelenecektir.

\section{1. İşsizlik Bağlamında Kayıt Dışı Ekonomi-Sosyal Politika Illişkisi}

İssizlik en genel anlamıyla, çalışma istek ve yeteneğinde olduğu halde piyasa ücret seviyesinde iş bulamama durumu olarak tanımlanabilir (Zaim, 1997, s. 170). 
İssizlik nedenleri, sonuçları ve diğer yönleriyle sosyal politikanın en temel uğraş alanlarındandır. Dolayısıyla kayıt dışı ekonomi ve işsizlik ilişkisi de sosyal politikayı yakından ilgilendirmektedir.

Literatürde kayıt dışı ekonomi ve işsizlik ilişkisini inceleyen çok sayıda ampirik çalışma yer almaktadır. Bu çalışmalardan bazılarının sonuçlarına bu başılı altında yer verilecektir. Bunlardan ilki Dell'Anno ve Solomon (2008)'un yapmış oldukları çalışmadır. Bu çalışmada Amerika Birleşik Devletleri'nde kayıt dışı ekonomi ve işsizlik ilişkisi incelenmiştir. Buna göre kayıt dışı ekonomi ve işsizlik arasında negatif bir ilişki olduğu ifade edilmiş, kayıt dışı ekonominin varlığının kayıtlı ekonomideki işsizliği azaltacağı belirtilmiştir. Kayıtlı ekonomideki küçülmenin işsizliğe neden olacağı ve bununda işsiz kalan bireyleri kayıt dışı ekonomiye yönlendireceği ifade edilirken aynı zamanda kayıt dışı ekonominin kayıtlı ekonomideki işsizliği hafifleterek buradaki küçülmenin olumsuz etkilerini azalttığı belirtilmiştir. Ayrıca çalışmada kayıt dışı ekonominin kayıtlı ekonomide harcanabilecek fazladan katma değer yaratmasının kayıtlı ekonomi üzerinde olumlu etkileri olduğu ifade edilmiş ve kayıt dışı ekonomide faaliyette bulunanların daha düşük gelir seviyelerinde olması nedeniyle kayıt dışı ekonomideki üretimin toplumdaki gelir dağılımı adaletine katkı sağlayacağı da belirtilmiştir. Kayıt dışı ekonomiye giriş-çıkışların kayıtlı ekonomiye göre daha kolay olması nedeniyle işgücünü arz ve talepteki değişikliklere karşı daha esnek hale getireceği, bunun da işgücü piyasasında rekabet gücünün geliştirilmesine katkı sağlayacağı ifade edilmiştir. Bajada ve Schneider (2009) yapmış oldukları çalışmada işsizlikten doğrudan etkilenen kayıt dışı ekonominin bileşenlerini araştırmışlar ve kayıt dışı ekonomi ile işsizlik arasındaki ilişkiyi ikame etkisi olarak nitelendirmişlerdir. Buna göre kayıtlı ekonomideki faaliyetlerin azalması ve işsizliğinde artması sonucunda ikame etkisinin arttığı ifade edilmiştir. Söz konusu çalışmada ikame etkisi yaklaşımıyla kayıt dışı ekonomi ve işsizlik oranlarındaki değişimin ilişkili olduğu sonucuna varılmıştır. Ayrıca çalışmada gerçekten kayıtlı ekonomiye geçmek isteyenler için işsiz oldukları süre boyunca kayıt dışı ekonominin finansal destek sağlayan bir kaynak olduğu da vurgulanmıştır. Uzun dönemli işsizlerin kayıt dışı ekonomiye dahil olabilecekleri olasılığı göz ardı edildiğinde, işsizlikteki kısa vadeli dalgalanmaların kayıt dışı ekonomide de kısa vadeli dalgalanmalara neden olduğu ifade edilmiştir. Dobre ve Alexandru (2009), İspanya üzerine yapmış oldukları çalışmada 1970-2007 
yılları arasını kapsayan dönem için işsizlik ve kayıt dışı ekonomi ilişkisini incelemişlerdir. Buna göre işsizlik oranlarında meydana gelen değişikliklerin kayıt dışı ekonominin büyüklüğünü etkilediği sonucuna ulaşmışlardır. Bir başka ifade ile işsizlik oranı ve kayıt dışı ekonomi oranı arasında pozitif bir ilişki olduğunu tespit etmişlerdir. Ayrıca çalışmada işsizliğin kayıt dışı ekonominin başlıca nedenlerinden biri olduğu ifade edilmiştir. Saraç (2012) Türkiye üzerine yapmış olduğu çalışmada 2000-2011 arasındaki işsizlik rakamlarını (çeyrek veriler) kullanarak eğitim düzeylerine göre işsizlik oranları ile kayıt dışı ekonomi ilişkisini incelemiş, kayıt dışı ekonominin boyutunu ise basit parasal yöntem ile ölçmüştür. Buna göre, lise ve dengi okul mezunlarının kayıt dışı sektörde çalışıkları ve tecrübelerinin artmasıyla birlikte kayıtlı sektöre geçtikleri tespit edilmiştir. Aynı çalışmada okur-yazar olmayan işsizlerin ise kayıt dışı sektörlerde çok tercih edilmemeleri nedeniyle bu grubun kayıtlı sektördeki işsizlik oranlarını hissedilir ölçüde azaltmadığı belirtilmiştir. Bu çalışma özelinde bir değerlendirme yapıldığında özellikle Türkiye'de tecrübesiz gençlerin iş bulamadığı göz önüne alınırsa kayıt dışı ekonomide faaliyet gösteren işletmelerde edinilen tecrübeyi, kayıtlı sektörün istediği tecrübeyi (şayet tecrübenin belgelendirilmesi istenmiyorsa) edinmek için bir staj gibi değerlendirmek mümkündür. Bu da kayıtlı sektöre geçişte büyük katkı sağlayacaktır. Dolayısıyla her ne kadar sosyal politika bağlamında istihdam politikaları incelendiğinde kayıt dışı ekonomide tecrübe edinilmesine dair bir politika olmasa da bu konuda kayıt dışı ekonominin bir fayda sağladığını ifade etmek yanlış olmayacaktır. Tabi ki bu kayıt dışı ekonominin özendirilmesi veya desteklenmesi anlamına gelmemektedir. Burada anlatılmak istenen, kayıt dışı ekonominin sosyal politika ile ilişkisi değerlendirildiğinde işsizlik bağlamında küçük de olsa böyle bir olumlu katkısının olduğudur. Adrianaa (2014) yapmış olduğu çalışmada 2000-2010 yılları arasında Romanya'da kayıt dışı ekonomi ve işsizlik ilişkisini incelemiştir. İşsizlikten kayıt dışı ekonomiye doğru tek yönlü bir nedensellik olduğunu tespit etmiştir. Yine Romanya için yapılan bir çalışmada Davidescu (2015), 2000-2010 arası işsizlik verileri ve kayıt dışı ekonomi verileriyle ekonometrik model kullanarak kayıt dışı ekonomi ve işsizlik ilişkisini incelemiştir. Buna göre hem ILO rakamları üzerinde hem de kayıtlı işsizlik oranları üzerinde kayıt dışı ekonominin kısa vadede istatistiksel olarak anlamlı ve olumsuz bir etkiye sahip olduğu tespit edilmiştir. Uzun vadede ise yine söz konusu işsizlik oranları üzerinde kayıt dışı ekonominin olumlu bir etkisi olduğu ifade edilmiştir. Ayrıca uyguladıkları 
nedensellik testine göre her iki işsizlik oranından kayıt dışı ekonomiye doğru tek yönlü bir nedensellik tespit edildiği belirtilmiştir. Saafi, Mohamed ve Farhat (2015)'ın Tunus üzerine yapmış oldukları çalışmada 1980-2009 yılları arasını kapsayan dönem için işsizlikten kayıt dışı ekonomiye doğru tek yönlü bir nedenselliğin olduğu tespit edilmiş ve yüksek işsizliğin kayıt dışı ekonomideki faaliyetleri artırdığı belirtilmiştir.

Literatürde birden fazla ülkeyi baz alarak yapılan çalışmalar da vardır. Mauleón ve Sardà (2016) Yunanistan, İspanya, Almanya ve İtalya'da kayıt dışı ekonomi ve işsizlik ilişkisini inceledikleri çalışmalarında özellikle 2008 krizinden sonra işsizliğin kayıt dışı ekonomi için daha önemli hale geldiğini ifade etmişlerdir. Söz konusu çalışmada işsizlik ve kayıt dışı ekonomi ilişkisinin işsizlik oranlarının yüksek olduğu Yunanistan ve İspanya'da anlamlı olduğu (iki değişkenin birbirini etkilediği) belirtilmiş, işsizlik oranlarının görece daha düşük olduğu Almanya ve İtalya'da anlamlı bir sonuca ulaşılamadığı ifade edilmiştir. Sahnoun ve Abdennadher (2019), yapmış oldukları çalışmada 38 gelişmekte olan ülke ve 40 gelişmiş ülke üzerinde kayıt dışı ekonomi ve işsizlik ilişkisini analiz etmişlerdir. Çalışmada gelişmekte olan ülkelerde işsizlikten kayıt dışı ekonomiye doğru tek yönlü ve negatif bir ilişki tespit edilmişken, gelişmiş ülkelerde ise kayıt dışı ekonomi ve işsizlik arasında çift yönlü ve negatif bir ilişki olduğu tespit edilmiştir. Çalışmada ayrıca kayıt dışı ekonominin nedenleri arasında olan yolsuzluk da dikkate alınarak gelişmekte olan ülkelerde kayıt dışı ekonomi ve yolsuzluk arasındaki etkileşimin işsizlik oranlarının artmasında önemli ve pozitif bir etkiye sahip olduğu belirtilmiştir. Yolsuzluğun yüksek düzeyde olmasının kayıt dışı ekonominin işsizliğe olan etkisini artırdığı ifade edilmiştir. Ayrıca bu durumun gelişmiş ülkelerde istatistiksel olarak bir etkisi olmadığı da belirtilmiştir. Çalışmada bu sonuçlar ışığında ülkelerin kurumsal kalitelerinin yüksek olması durumunda işsizlik ve kayıt dışı ekonomi ilişkisinin zayıf olacağı fakat kurumsal kalite düşükse işsizlik ve kayıt dışı ekonomi ilişkisinin güçlü bir ilişki olacağı ifade edilmiştir.

Genel olarak işsizlik bağlamında kayıt dışı ekonomi ve sosyal politika ilişkisi ele alındığında bu ilişkinin önem derecesinin yüksek olduğunu ifade etmek mümkündür. Nitekim kayıt dışı ekonomide işsizlik nedeniyle bulunanların işsizliğin yıkıcı etkilerinden korunmasının yanında işsizliğin, kayıt dışı ekonomiyi büyüttüğü 
de ortaya çıkan sonuçlardan biridir. Yani işsizlik bağlamında kayıt dışı ekonomi ve sosyal politika ilişkisinin birden fazla kaynağı vardır. Dolayısıyla işsizlikle ilgili sosyal politikalar yapılırken kayıt dışı ekonominin boyutu da göz önüne alınmalıdır.

\subsection{Gelir Dağılımı ve Yoksulluk Bağlamında Kayıt Dışı Ekonomi-Sosyal Politika İlişkisi}

Gelir en genel anlamda, mal veya hizmet üretilmesiyle ortaya çıkan ayni veya nakdi getiri şeklinde tanımlanabilir. Gelir dağılımı ise, bu getirinin bireyler arasındaki dağılımını ifade etmektedir. Yoksulluk kavramı da farklı türleri ve farklı tanımları olmakla birlikte en genel anlamıyla, ihtiyaçlarını karşılamaktan yoksun olma durumu olarak ifade edilebilir (Koray, 2018, s. 306-307). Yine gelir dağılımı ve yoksulluk sosyal politikanın temel uğraş alanlarındandır. Sosyal politika yoksulluğun azaltılması, ortadan kaldırılması, gelir dağılımı adaletinin sağlanması; kısaca toplumun refahının artıılmasını hedeflemektedir. Dolayısıyla kayıt dışı ekonominin gelir dağılımı ve yoksulluğa etkileri sosyal politika açısından önem arz etmektedir.

Gelir dağılımı ve kayıt dışı ekonomi üzerine yapılan ampirik çalışmalardan, Rosser, Rosser ve Ahmed (2000)'in çalışmalarında, 16 geçiş ekonomisi üzerinde gelir eşitsizliği ve kayıt dışı ekonomi ilişkisi incelenmiş ve gelir eşitsizliği seviyesi ile kayıt dışı ekonomi oranı arasında çift yönlü ve pozitif bir etki tespit edilmiştir. Dolayısıyla gelir dağılımı adaletini sağlamaya yönelik politikaların kayıt dışı ekonomiyi de kontrol altına almaya yarayabileceği vurgulanmıştır. Kar ve Saha (2012)'nın Asya için yolsuzluk, kayıt dışı ekonomi ve gelir eşitsizliği ilişkisini inceledikleri çalışmada, kayıt dışı ekonomi ve yolsuzluk göstergelerinin birlikte analiz edildiğinde gelir eşitsizliğine etkisinin daha az olduğu ifade edilmiştir. Çalışmada kayıt dışı ekonominin büyümesinin işsiz kalacak bireylerin veya grupların kayıt dışı sektöre yönelmeleriyle gelirlerini artıracağı belirtilmektedir. Çalışmada elde edilen bulgulara göre yolsuzluk arttıkça kayıt dışı ekonominin genişlediği ve bunun da gelir eşitsizliğini azalttığı sonucuna ulaşılmıştır. Kayıt dışı ekonomi ve gelir dağılımı konusundaki bir diğer çalışmada Georgiou (2013), kayıt dışı ekonominin küçülmesinin gelir dağııımını kötüleştirmeyeceğini ifade etmiştir. Buna göre, kayıt dışı ekonomik faaliyetlerin kayıt altına alınması ile girişimcilik 
yoluyla ekonomik büyümenin sağlanabileceği ve girişimciliğin işsizliği azaltacağı, bunun da gelir dağılımına olumlu katkılarının olacağı ifade edilmiş̧ir. Williams (2014) tarafından yapılan çalışmada ise sınırlı veriler olsa bile bireylerin kayıt dışı ekonomide daha uzun süreler çalışmalarına rağmen daha az fayda sağladıkları; bunun da kayıtlı ekonomide ortaya çıkan gelir eşitsizliklerini azaltmak yerine daha fazla artırdığı ifade edilmiştir. Gasteratos, Karamalis ve Koutoupis (2016)'in çalışmalarında çeşitli Avrupa ülkeleri üzerinde ekonometrik model yardımıyla inceleme yapılmıştır. Buna göre vergi kaçaklarının gini katsayısını büyüttüğünden bahsedilmiş ve gelir dağılımının bozulduğu belirtilmiştir. Gini katsayısındaki bu artışın uzun vadede halihazırda kayıtlı ekonomide faaliyet gösterenleri etkileyeceği ve kayıt dışı ekonomiyi büyüteceği ifade edilmiştir. Bunun da ekonomik büyümenin önünde bir engel oluşturacağı vurgulanmıştır. Ayrıca çalışmada, kayıt dışı ekonominin etkisiyle gelir dağılımının kötüleşeceği ve bunun da yoksulluğu artıracağı ifade edilmiştir. Bu durumun da uzun vadede bazı sosyal problemlere neden olacağı belirtilmiştir. Elveren ve Özgür (2016)'ün Türkiye üzerine 19632008 yılları arasını kapsayan gelir eşitsizliği ve kayıt dışı ekonomi ilişkisini inceledikleri çalışmalarında Türkiye'de 1980'lerde neoliberal ekonomi politikalarının etkisiyle gelir eşitsizliğinin arttığı ve kayıt dışı ekonominin büyüdüğü ifade edilmiştir. Çalışmada kayıt dışı ekonominin, kayıtlı ekonomide iş bulamayan ve bu nedenle daha kötü çalışma koşullarını ve daha düşük ücretleri kabul etmeye istekli olan düşük vasıflı işçiler açısından bir alternatif olduğu için kayıt dışı ekonomi ve gelir eşitsizliği arasında güçlü bir ilişki olduğu vurgulanmıştır. Çalışmada elde edilen bulgulara göre dış ticaret rekabeti, işsizlik, gelir eşitsizliği ve kayıt dışı ekonomi arasında güçlü bir bağlantı vardır. Ayrıca kayıt dışı ekonomi ve işsizlik arasındaki ilişkinin, ekonomik durgunluk dönemlerinde en ciddi iş kayıplarının kayıt dışı sektörlerde olması nedeniyle, negatif olduğu belirtilmiştir.

Literatürde, kayıt dışı ekonomi ve yoksulluk arasındaki ilişkiyi inceleyen çalışmalar da yer almaktadır. Genel olarak bakıldığında dünyada yoksulluk arttıkça kayıt dışı ekonominin boyutunun da arttığı görülmektedir (Firoozabadi, Razmi ve Bahmani, 2015, s. 527). Elijah ve Uffort (2007) ülkelerin farklı gelişmişlik düzeylerine göre yapmış oldukları çalışmalarında kayıt dışı ekonomi ve yoksulluğun herhangi bir coğrafi sınıra sahip olmadığını ifade etmişlerdir. Gelişmekte olan 
ülkeler ve geçiş ülkelerinde, gelişmiş ülkelerle kıyaslandığında yoksulluk ve kayıt dışı ekonominin oranlarının daha büyük olduğunu vurgulamışlardır. Ayrıca kayıt dışı ekonomi ve yoksulluk arasında bir nedensellik ilişkisi olduğunu belirtmişler, özellikle gelişmekte olan ülkelerde ve geçiş ülkelerinde yoksulluk ve kayıt dışı ekonominin her ikisini de etkileyen yüksek işsizlik ve yolsuzluk gibi nedenlerin bu ilişkide önemli rol oynadığını ifade etmişlerdir. Danopoulos ve Znidaric (2007)'in Yunanistan için kayıt dışı ekonomi, vergi kaçırma ve yoksulluk üzerine yapmış oldukları çalışmalarında kayıt dışı ekonominin ve vergi kaçırmanın kısa vadede fayda sağlasa bile uzun vadede devletin yoksulluğu azaltmaya ve gelir dağılımı adaletini sağlamaya yönelik politikalarına zarar verebileceği ifade edilmiştir. Aryeetey (2009)'in yapmış olduğu çalışmada kayıt dışı ekonominin, yoksulluğun azaltılmasına yaptığı katkının istihdam aracılığıyla olduğu ifade edilmiş ve istihdam fırsatlarının yetersiz olmasının insanları kayıt dışı ekonomiye yönlendirdiği belirtilmiştir. Kayıt dışı ekonomide çalışanların düşük ücret almalarının onları kayıt dışı ekonomiye yönlendirmeye devam edeceği belirtilmiş, bunun nedeni olarak da kayıt dışı ekonominin yoksullar için alternatif bir geçim kaynağı olduğu vurgulanmıştır. Kayıt dışı ekonomideki işlerin ücretlerinin düşük olmasıyla birlikte çalışma şartlarının kötü olmasının da yoksulluğun azaltılmasına katkı sağlamadığı ifade edilmekte; dolayısıyla yoksulluğun bireyleri kayıt dışı ekonomiye yönlendirdiği, kayıt dışı ekonominin de bireyleri yoksullaştırdığı belirtilmektedir. Ayrıca bu çalışmada kayıt dışı ekonomide faaliyet gösterenlerin kayıtlı ekonomide faaliyet gösterenlere göre büyük bir bölümünün yoksul hanelerden geldiği ve yoksul hanelerdeki hane halklarının elde ettikleri gelirlerin yoksul olmayan hanelere göre daha büyük bir bölümünün kayıt dışı ekonomiden sağlandığı ifade edilmektedir. Nikopour ve Muzafar (2010) yapmış oldukları çalışmada 139'u gelişmekte 23'ü gelişmiş toplamda 162 ülkede 1999-2007 arası yıllar için kayıt dışı ekonomi ve yoksulluk ilişkisini panel veri analizi ile incelemişlerdir. Buna göre gelişmekte olan ülkelerde kayıt dışı ekonominin büyümesinin yoksulluğu artırdığı, gelişmiş ülkelerde yoksulluğu azalttığı sonucuna ulaşmışlardır.

Yukarıda bahsedilen ampirik çalışmalardan da anlaşılacağı üzere kayıt dışı ekonominin gelir dağılımı üzerinde hem olumlu hem de olumsuz etkileri olduğu görülmektedir. Yoksulluk bağlamında inceleme yapıldığında ise farklı gelişmişlik 
seviyelerine göre farklı sonuçlar ortaya çıkmaktadır. Fakat gelir dağılımı adaletinin sağlanamadığı ülkelerde genel olarak yoksulluk oranı artmaktadır. Bu nedenle kayıt dışı ekonomi her ne kadar gelişmiş ülkelerde yoksulluğu azaltsa da uzun vadede gelir dağılımı adaletini bozacağı için yoksulluğu artırabileceğini ifade etmek mümkündür. Dolayısıyla gelir dağılımı ve yoksulluk bağlamında ele alındığında kayıt dışı ekonomi sosyal politika açısından önem arz etmektedir.

\subsection{Göç Bağlamında Kayıt Dışı Ekonomi-Sosyal Politika Illişkisi}

Göç en genel anlamda, çeşitli nedenlerle bireylerin veya grupların bulundukları yerden başka bir yere gitmeleri olarak ifade edilebilir. Olumlu ve olumsuz taraflarıyla insanları bir şekilde etkileyen göç insanlık tarihi kadar eski bir olgudur. Sosyo-kültürel olarak çok geniş bir yapıya sahip olan göç hızlı değişimlerin olduğu ülkelerdeki önemli sorunlardan biri olmakla birlikte, sosyal politikanın temel uğraş alanlarının içinde yer almaktadır (Esenlikci ve Engin, 2019, s. 61).

Bohn ve Owens (2009), Amerika'da inşaat ve çevre düzenleme sektörlerinde kayıt dışı ekonomi ve göç ilişkisini inceledikleri çalışmalarında söz konusu sektörlerde kayıt dışı ekonominin büyümesinin nedenlerinden birinin illegal göç olduğunu ifade etmişlerdir. Kırbaş (2012, s. 32-33) Türkiye özelinde yapmış olduğu değerlendirmede, yoğun göçlerin çarpık kentleşmeye sebep olduğunu ifade etmiş, kente göç edip işsizlik ve barınma sorunu yaşayan insanların devlet arazilerini işgal ettiklerini vurgulamıştır. Bunun da gecekondulaşmayı artırdığını ve gecekondulaşmanın da işportacılığı beraberinde getirdiğini ve kayıt dışı ekonominin büyümesine katkı sağladığını belirtmiş̧ir. Aynı zamanda, niteliksiz işgücünün göçle birlikte köyden kente gelmesi ve kentte daha az ücret ve sosyal güvence olmaksızın çalışması da kayıt dışı ekonomiyi büyütmektedir (Sugözü, 2010, s. 48). Dolayısıyla göç ve kayıt dışı ekonomi ilişkisi kendisini daha çok kayıt dışı istihdam bağlamında göstermektedir. Bosh ve Farré (2013), İspanya üzerine kayıt dışı işgücü piyasası ve göç ile ilgili yapmış oldukları çalışmalarında, 2000-2009 yılları arasında İspanya'daki yabancı doğumlu nüfusta (İspanya dışında doğan nüfus) gerçekleşen \%12'lik bir artışın kayıt dışı istihdamda gerçekleşen artışın en az \%70'lik kısmını oluşturduğunu ifade etmişlerdir. 2005 yılında İspanya'da 700.000 kayıt dışı 
yabancı işçiye çalışma izni verildiği belirtilmiş ve çalışma izni verilenlerin kayıt altına alınmasıyla kayıt dışı istihdam oranının \%2 azaldığı belirtilmiştir. Camacho, Mariani ve Pensieroso (2017) yapmış oldukları çalışmada yasadışı göç ve kayıt dışı ekonomi ilişkisini incelemişlerdir. Söz konusu çalışmada, ev sahibi ülkedeki kayıt dışı ekonominin büyüklüğünün potansiyel göçmenlerin yasadışı olarak göç etmelerini teşvik edeceği veya engelleyeceği ifade edilmiştir. Daha açık bir ifadeyle, ev sahibi ülkede kayıt dışı ekonominin boyutu büyükse o ülkeye yasadışı göç daha fazla olacaktır. Eğer kayıt dışı ekonomi küçükse yasadışı göç daha az olacaktır veya olmayacaktır. Buradan da anlaşılacağı üzere kayıt dışı ekonominin boyutunun büyük olduğu ülkelere göç edenler bakımından kayıt dışı ekonominin göçün çekici faktörleri arasında olduğu ifade edilebilir.

Dolayısıyla göç bağlamında kayıt dışı ekonominin sosyal politika açısından önemli olduğunu ifade etmek mümkündür.

\subsection{Kayıt Dışı İstihdam Bağlamında Kayıt Dışı Ekonomi-Sosyal Politika ilişkisi}

Kayıt dışı istihdam en genel haliyle, çalışanların çalışmalarının ilgili kurumlara hiç bildirilmemesi veya eksik bildirilmesi nedeniyle gerekli yükümlülüklerden kaçınmak ve herhangi bir sosyal güvenlik kurumuna bağlı olmaksızın çalışmak veya çalıştırmak şeklinde tanımlanabilir (Tekinarslan, 2014, s. 47). Kayıt dışı istihdam, kayıt dışı ekonominin en bilinen ve en önemli faaliyet alanlarından biridir (Altuğ, 1999, s. 11). Ayrıca kayıt dışı istihdam nedenleri-sonuçları ve diğer yönleriyle eskiden beri sosyal politika literatürünün önemli konuları arasında yer almış ve bu konuda oldukça fazla çalışma yapılmıştır. Şöyle ki kayıt dışı istihdama yoksulluk ve gelir dağılımı adaletsizliği veya göç neden olabilirken aynı problemler sonuç olarak da değerlendirilebilmektedir. Bu da kayıt dışı istihdamın nedenleri ve sonuçları arasında bir kısır döngünün olduğunu göstermektedir.

Kayıt dışı istihdamın temel özellikleri şu şekilde ifade edilebilir (Mahiroğulları, 2017, s. 549-550):

- Kayıtsız çalışma

- Sisteme girişin kolay olması 
- Yasal mevzuata uyulmayarak kuralsız ve esnek çalışma

- Ölçümünün zor olması

- Genellikle vasıfsız işçilerin yaygın olduğu emek yoğun çalışma

- Genel olarak küçük işletmelerde yaygın olması

Kayıt dışı istihdamın türleri de şu şekilde sıralanabilir ( Dereli, 2007, s. 69-70; Tekinarslan, 2014, s. 57-65):

- Çalışmaları hiçbir kuruma bildirilmeyenler (işportacılar, evlerde yapılan imalatın satış ve hizmet faaliyeti gibi)

- Yabancı kaçak işçiler

- Çocuk işçiler

- Çalışmaları ilgili kurumlara kısmen bildirilenler

- Çalışılan gün sayısının eksik bildirilmesi

- Ödenen ücretin eksik bildirilmesi

- Sosyal güvenlik kurumundan gelir ve aylık alanlar (genç yaşta emekli olup işverenler tarafından halihazırda sigorta primi gibi mali yükleri olmayanların tercih edilmesi)

Kayıt dışı istihdam ve kayıt dışı ekonomi arasında oldukça yakın bir ilişkiden bahsetmek mümkündür. Bu bağlamda kayıt dışı istihdamın çeşitli yönlerinden bahsedilirken kayıt dışı ekonomiden bağımsız düşünmek yanlış olacaktır (Güloğlu, Adem ve Murat, 2003, s. 53). Kayıt dışı istihdamın neden ve sonuçları genel olarak kayıt dışı ekonominin neden ve sonuçlarıyla aynıdır. Burada kısaca birkaç nedene değinilecektir. Buna göre kayıt dışı istihdam özelinde kayıt dışı ekonominin de nedenleri arasında sayılabilecek ilk husus çocuk iş̧̧iliğidir. Çocuk iş̧̧iler, genel olarak kırsal kesimde düşük ücretli ve kayıt dışı tarım işçisi olarak istihdam edilirken kentlerde ise ayakkabı boyacılığı, su satışı, gazete dağııımı gibi sektörlerde kayıt dışı faaliyet göstermektedir (Dam, Ertekin ve Kızılca, 2018, s. 300). Çocuk iş̧̧ilerin kayıt dışı istihdamda yer alması ahlaki ve psikolojik yönden zarar görmelerine neden olabilmektedir. Aynı zamanda çocuk yaşta çalışmalarının eğitimlerini engellediği gerçeğinden hareketle suç işlemeye yönelebileceklerini ve bu sektörde çalışan çocukların eğitimini tamamlayamadığı düşünüldüğünde de kayıtlı ekonomide istihdam edilmelerinin zorlaştığını ifade etmek mümkündür (Güloğlu ve ark., 2003, s. 
60). Ülkelerdeki toplu iş hukuku mevzuatının katı olması da kayıt dışı istihdama neden olabilmektedir. İsverenler iş̧̧ilerin sendikalaşarak pazarlık gücünün artmaması için kayıt dışı istihdama yönelmekte veya taşeron işletmeler aracılığıyla riski dağıtma yoluna gitmektedir (Kaleli ve Karaca, 2019, s. 773-775). Bu da kayıt dışı istihdam edilenler açısından çeşitli hak kayıplarına sebep olmaktadır.

Kayıt dışı istihdamın etkileri incelendiğinde kayıt dışı ekonominin olumlu ve olumsuz etkileri ile aynı sonuçlar ortaya çıkmaktadır. Bu nedenle çok detaylı incelenmeyecektir. Sosyal politika bağlamında bazı sorunların ortaya çıkmasına neden olabilecek birkaç hususa değinmek yerinde olacaktır. Buna göre kayıt dışı istihdam edilenler, sosyal güvenlik primlerinin ödenmemesi nedeniyle kısa vadede kısa süreli yardım almasını gerektirebilecek risklere karşı koruma sağlayan sigorta kollarından (iş kazası, meslek hastalığı, analık gibi) faydalanamazken, uzun vadede de uzun süreli risklere karşı koruma sağlayan sigorta kollarından (yaşlılık, malullük, ölüm) yararlanamamaktadır (Oktar, 2004, s. 268-270). Bu sorunlarda, riskler ortaya çıktığında kişinin mevcut gelirinin daha da azalmasına ya da iş kazası gibi durumlarda herhangi bir haktan yararlanamamasının yanında geçici iş göremezlik ödeneği gibi çeşitli ödeneklerden de faydalanamaması sebebiyle daha fazla yoksullaşmasına neden olabilecektir.

Kayıt dışı istihdam daha çok kadınlar, çocuklar ve gençler arasında yaygındır. Dünyadaki gençlerin çoğu, kayıt dışı istihdam edilmekte, güvencesiz ve geçici işlerde çalışmaktadırlar. Bu da işgücü piyasasının en dinamik gücü olan gençlerin yeteneklerinden tam yararlanılamamasına ve gençlerin toplumsal refaha katkı sağlayamamalarına neden olmaktadır. Gençler bu sebeplere bağlı olarak sürekli iş değiştirmekte ve işsizlik dönemleri tekrarlanıp uzamaktadır (Çetinkaya, 2008, s.116). Dünya nüfusunun yarısı kadınlardan oluşsa da kadınlar ve erkekler arasında birçok alanda eşitliğin olmadığı ifade edilmektedir. Dolayısıyla kayıtlı istihdamda daha az yer alan kadınların kayıt dışı istihdamdan en çok etkilenen dezavantajlı gruplardan olduğunu ifade etmek mümkündür (Öztürk ve Başar, 2018, s. 42). 
Tablo 1: Dünyada 2016 Yılı Kayıt Dışı İstihdam Oranları (\%)

\begin{tabular}{|l|c|c|c|c|c|c|}
\hline & Afrika & Amerika & $\begin{array}{l}\text { Arap } \\
\text { Ülkeleri }\end{array}$ & $\begin{array}{l}\text { Asya ve } \\
\text { Pasifik }\end{array}$ & $\begin{array}{l}\text { Avrupa } \\
\text { ve Orta } \\
\text { Asya }\end{array}$ & Toplam \\
\hline \multicolumn{7}{|l|}{ Kayıt Dışı İstihdam ve Bileşenlerinin Toplam İstihdam İçindeki Payı } \\
\hline Toplam İstihdam & 85.8 & 40.0 & 68.6 & 68.2 & 25.1 & 61.2 \\
\hline Kayıt Dışı Sektörde & 76.0 & 29.3 & 60.9 & 58.8 & 19.4 & 51.9 \\
\hline Kayıtlı Sektörde & 5.5 & 7.9 & 7.5 & 6.9 & 5.3 & 6.7 \\
\hline Evde & 4.3 & 2.7 & 0.3 & 2.5 & 0.5 & 2.5 \\
\hline Çalışanlar & 56.8 & 25.9 & 54.3 & 49.8 & 15.4 & 39.7 \\
\hline Kayıt Dışı Sektörde & 33.7 & 13.4 & 42.7 & 36.0 & 9.7 & 26.7 \\
\hline Kayıtlı Sektörde & 18.9 & 9.4 & 11.4 & 11.8 & 5.5 & 10.8 \\
\hline Evde & 4.2 & 3.1 & 0.2 & 2.0 & 0.3 & 2.1 \\
\hline $\begin{array}{l}\text { Tarım Dışı Sektörlerdeki Kayıt Dışı İstihdamın ve Bileşenlerinin Tarım Dışı Sektörlerdeki } \\
\text { İstihdamdaki Payı }\end{array}$ & 71.9 & 36.1 & 63.9 & 59.2 & 20.9 & 50.5 \\
\hline Toplam İstihdam & 59.2 & 26.0 & 55.1 & 48.9 & 15.2 & 40.8 \\
\hline Kayıt Dışı Sektörde & 9.4 & 7.2 & 8.7 & 8.8 & 5.4 & 8.0 \\
\hline Kayıtlı Sektörde & 3.4 & 2.9 & 0.1 & 1.4 & 0.3 & 1.6 \\
\hline Evde
\end{tabular}

Kaynak: ILO, 2018, s.23

Tablo 1 incelendiğinde 2016 yılında toplam istihdam içerisinde kayıt dışı istihdamın en yüksek olduğu ülke gruplarının sırasıyla Afrika, Arap Ülkeleri, Asya ve Pasifik Ülkeleri, Amerika, Avrupa ve Orta Asya Ülkeleri şeklinde olduğu görülmektedir. Bu sıralamayı sağlayan rakamlardan hareketle dünya genelinde toplam istihdam içerisinde yer alan kayıt dışı istihdamın oranının 2016 yılında \%50'den fazla olduğu tahmin edilmiştir. Dünya'daki istihdamın yarıdan fazlasının kayıt dışı ekonomi kapsamında olduğu göz önüne alınırsa kayıt dışı istihdam bağlamında ortaya çıkacak her türlü ekonomik veya sosyal sorunun sadece ülkeleri veya ülke gruplarını değil bütün dünyayı etkileyeceğini, bu sorunun küresel bir sorun olduğunu ifade etmek yanlış olmayacaktır. Dolayısıyla kayıt dışı istihdam bağlamında alınacak sosyal politika kapsamındaki her türlü önlem kayıt dışı ekonominin büyümesini engelleyecek ya da kayıt dışı ekonominin olumsuz etkilerini bertaraf etmeye destek olacaktır.

\footnotetext{
2 ILO'nun bölgelere göre yayınladığı en güncel oranlar 2016 yılı içindir. Çalışmanın konusu herhangi bir ülkeyi içermediği için tablodaki veriler kullanılmıştır.
} 


\section{Sonuç}

Devletlerin sosyal politikaları uygulama başarısı ekonomisinin büyüklüğüne ve gücüne bağlıdır. Bu nedenle ekonomiyi etkileyen herhangi bir konu doğrudan veya dolaylı olarak sosyal politikayı da etkilemekte ve bu bağlamda sosyal politika ekonomi ilişkisi büyük önem arz etmektedir. Bu çalışmada buradan hareketle kayıt dışı ekonomi ve sosyal politika ilişkisi üzerine yoğunlaşmış ve sosyal politikanın temel uğraş alanlarından olan işsizlik, gelir dağılımı-yoksulluk, göç ve kayıt dışı istihdam bağlamında bir inceleme yapılmıştır.

Kayıt dışı ekonomi ve işsizlik ilişkisi incelendiğinde literatürdeki çalışmalar bu ilişkinin hem olumlu hem de olumsuz taraflarını ele almaktadır. Olumlu etkiler genel olarak kayıt dışı ekonominin işsizliği azalttığı veya işsizliğin yıkıcı etkilerine karşı bir tampon görevi gördüğü şeklinde ifade edilmektedir. Olumsuz etkileri ise genel olarak kayıt dışı sektördeki çalışma şartlarının kayıtlı sektördekine oranla çok daha kötü olmasından kaynaklanmaktadır. Dolayısıyla literatürdeki bu ayrılık bağlamında önceliğin kayıt dışı ekonominin küçültülmesine mi yoksa işsizliğin azaltılmasına mı verilmesi gerektiği de tartışmalıdır. Dell'Anno ve Solomon (2008)'a göre devlet kayıt dışı ekonomiyi tamamen bitirmekle uğraşmak yerine kayıtlı ekonomiye geçişi teşvik etmeye odaklanmalıdır. Dolayısıyla buradan çıkan sonuç kayıt dışı ekonominin işsizlik üzerindeki olumlu etkileri göz önüne alınarak çok yüksek olmayan seviyelerde tutulmasının yararlı olacağıdır. Saafi, Mohamed ve Farhat (2015)'a göre ise kayıt dışı ekonomiyi küçültmek yerine işsizliğin azaltılmasına odaklanılmalıdır. Dolayısıyla bireyler işsiz kalmadıklarında kayıt dışı sektörlerdeki olumsuz çalışma şartlarına maruz kalmayacaklardır. Kayıt dışı ekonominin büyüme riskinin olduğu ülkelerde kayıtlı ekonomide istihdama teşvik verilmeli ve işsiz kalan bireylerin kayıt dışı ekonomiye geçişleri engellenmelidir. Bunun için bireylerin işten çıkarılmasının önüne bir engel koyulmalı ve devlet kıdem tazminatı miktarlarını yükselterek iş̧̧i ücretlerindeki yasal kesintileri düşürmelidir. Ayrıca kayıt dışıllk riski yüksek olan ekonomilerde, söz konusu riskin düşük olduğu ekonomilere göre işsizlik yardımları yüksek olmamalıdır (Espino ve Sánchez, 2015). Bireylerin kayıt dışı ekonomiye geçmesindeki temel etkenlerden birinin fayda maksimizasyonu olduğu düşünüldüğünde, işsizlik yardımlarının yüksek olması kayıt dışı ekonomiye yönelişi artıracaktır. 
Gelir dağılımının ve yoksulluğun kayıt dışı ekonomi ile ilişkisi incelendiğinde yapılan ampirik çalışmalarda bu ilişkinin hem olumlu hem de olumsuz tarafları olduğuna yönelik sonuçlar ortaya çıkmıştır. Söz konusu ilişkinin olumlu tarafları olduğuna dair sonuçlar kayıt dışı ekonominin gelir eşitsizliğini ve yoksulluğu azalttığını gösterirken, olumsuz olduğuna dair sonuçlarda bu ilişkinin gelir eşitsizliğini ve yoksulluğu artırdığını ortaya koymaktadır. Fakat genel kanı, kayıt dışı ekonominin gelir eşitsizliğine sebep olduğudur. Birleşik Krallıkta yapılan bir çalışmanın sonuçlarına göre referans alınan dönem içerisinde kayıt dışı sektörlerde çalışanların oranı düşük gelirli bölgelerde yüksek gelirli bölgelere göre daha fazladır. Aynı zamanda kayıt dışı sektörlerde çalışan düşük gelirli hanelerin aynı sektörde çalışan yüksek gelirli hanelere göre yıllık ortalama gelirleri daha düşüktür (Williams, 2014, s. 3). Yine Birleşik Krallık'ta yapılan bir başka çalışmaya göre kayıt dışı ekonomide faaliyette bulunanların kayıtlı ekonomide faaliyette bulunanlara göre saatte \%28 daha az kazanç sağladığı tespit edilmiştir (Williams, 2014, s. 14). Bu bilgiler ışığında daha eşitsiz bir ekonomi olan kayıt dışı sektörde üretilen ucuz ürünleri yoksulların talep etmesi de daha büyük bir kayıt dışı sektör ortaya çıkaracaktır. Ayrıca kayıt dışı ekonominin büyümesi ile vergi gelirlerinin ve sosyal güvenlik prim gelirlerinin azalmasına bağlı olarak devletin gelir dağılımı adaletini sağlamaya yönelik refah programlarının fonları sınırlanacak ve bu da gelir eşitsizliğinin artmasına neden olacaktır (Elveren ve Özgür, 2016, s. 296 - 299). Aryeetey (2009, s. 27)'e göre dünyada 1 doların altında gelir elde eden insanların büyük bir bölümü kayıt dışı sektörde çalışmaktadır. Dolayısıyla kayıt dışı ekonomiye odaklanılmadan yoksulluk sorunu çözülemeyecektir.

Kayıt dışı ekonominin göç ile ilişkisi değerlendirildiğinde göçün kayıt dışı ekonomiyi büyüttüğü, göç edenlerin genelde maddi kaygılarla göç etmesine bağlı olarak göç ettikleri yerlerde yoksulluk, işsizlik gibi sorunlardan kendilerini kurtarabilmek adına kayıt dışı ekonomiye yöneldikleri bilinmektedir. Bunun yanında kayıt dışı ekonominin büyüklüğünün yasa dışı göç bakımından çekici faktör olduğunu da ifade etmek mümkündür. Aynı zamanda yasal statüsü olsa bile çoğu göçmen kayıt dışı sektörde iş bulabilmektedir (Reyneri, 2003, s. 15). Göç edenlerin kayıt dışı sektörlere yönelmelerindeki en önemli etkenlerin niteliksiz işçilerin çalışma izni almalarındaki zorluk, yabancıların çalışmalarının yasaklandığı 
işlerin çok olması ve işverenlerin daha az maliyetli oldukları için göç edenleri istihdam etmesi olarak sıralanabilir (Aslantürk ve Tunç, 2018, s. 19). Dolayısıyla göç edilen ülkede de işçi maliyetleri nedeniyle göç edenlere talep olması kayıt dışı ekonomiyi büyütmektedir. Bu da daha fazla ekonomik ve sosyal soruna sebep olmaktadır. Göç edenler için resmi istihdam fırsatlarının sağlanması hem kayıt dışı ekonominin büyümesini engelleyecek hem de sosyal yardım gibi giderlerin azalmasını sağlayarak devletin bütçesine katkı sağlayacaktır. Devletin doğrudan illegal göçe müdahale ederek kayıt dışı ekonominin ve diğer problemlerin önüne geçebilmesi çok mümkün gözükmemektedir. Bunun yerine işveren ve işçileri (göçmen) çevreleyen sosyal ve politik durum ele alınmalı ve bunların çözümüne odaklanılmalıdır (Maroukis, Iglicka ve Gmaj, 2011, s. 147).

Kayıt dışı istihdam kayıt dışı ekonominin işgücü piyasalarına yansımasıdır. Yukarıda ele alınan konular tamamen kayıt dışı ekonomide çalışanların, yani kayıt dışı istihdam edilenlerin çevresinde şekillenmektedir. Dolayısıyla kayıt dışı istihdam, kayıt dışı ekonomi-sosyal politika ilişkisinin her safhasında göz önüne alınmalı ve değerlendirilmelidir. Kayıt dışı istihdamın önlenmesi sosyal politika literatüründe en çok incelenen konulardan biridir. Bu nedenle bu çalışmada bu konuya çokça yer verilmese de daha geniş bir kavram olan kayıt dışı ekonomiyi kayıt dışı istihdamın beslediği ifade edilmelidir. Şöyle ki insanlar kayıt dışı ekonomiye hem emeklerini arz ederek katılabilirken hem de kayıt dışı ekonomide üretilen ürünleri talep ederek (daha çok kayıt dışı istihdam edilen yoksullar) kayıt dışı ekonomiyi beslemektedir.

Sonuç olarak, sosyal politikalar yapılırken kayıt dışı ekonominin göz önüne alınmaması mevcut sosyal sorunu daha da derinleştirebilecektir. Fakat önceliğin kayıt dışı ekonomiye mi, işsizlik ve yoksulluk gibi temel sorunlara mı verileceği ülkenin sosyo-ekonomik durumuna göre iyi değerlendirilmelidir. 
Hakem Değerlendirmesi: Dış bağımsız.

Çıkar Çatışması: Yazar çıkar çatışması bildirmemiştir.

Finansal Destek: Yazar bu çalışma için finansal destek almadığını beyan etmiştir.

Peer-review: Externally peer-reviewed.

Conflict of Interest: The author has no conflict of interest to declare.

Grant Support: The author declared that this study has received no financial support.

\section{Kaynaklar/References}

Adrianaa, D. (2014). Revisiting the relationship between unemployment rates and shadow economy. A Toda Yamamoto approach for the case of Romania. Procedia Economics and Finance, 10(2014), 227-236.

Akbaş, E. (2019). Sosyal politikaya giriş: Tarihsel ve eleştirel bir çerçeve. A. Develi ve E. T. Karagöl (Ed.), Sosyal politika: Teori, politika ve uygulamalar içinde (s. 9-30). Kocaeli: Umuttepe Yayınları.

Altuğ, O. (1999). Kayıtdışı ekonomi (2.Baskı). İstanbul: Türkmen Kitabevi.

Amenta, E. (1998). Book rewiew of the hidden welfare state: Tax expenditures and social policy in the United States. The American Journal of Sociology, 948-950.

Arandarenko, M. (2015). The shadow economy: Challenges to economic and social policy. In G. Krstic ve F. Schneider (Ed.), Formalizing the shadow economy in Serbia: Policy measures and growth effects (pp. 5-12). New York-Londra: Springer Open.

Aryeetey, E. (2015). The informal economy, economic growth and poverty in Sub-Saharan Africa. In A. McKay \& E. Thorbecke (Ed.), Economic Growth and Poverty Reduction in Sub-Saharan Africa: Current and Emerging Issues (pp. 159-196). Oxford: Oxford University Press.

Aslantürk, O. ve Tunç, Y. E. (2018). Yabancıların Türkiye'de kayıt dışı istihdamı. Aksaray Üniversitesi İktisadi ve İdari Bilimler Fakültesi Dergisi, 10(4), 13-20.

Bajada, C. \& Schneider, F. (2009). Unemployment and the shadow economy in the OECD. Revue Economique, 60, 1033-1067.

Bohn, S. \& Owens, E. G. (2009). Immigration and the informal economy. Retrieved from http:// citeseerx.ist.psu.edu/viewdoc/summary?doi=10.1.1.492.7248.

Bosh, M. \& Farré, L. (2013). Immigration and the informal labor market. IZA Discussion Paper, 7843.

Bozkurt, C. (2014). Kayıtdışı ekonominin bir değerlendirmesi ve Türkiye. Gaziantep University Journal Of Social Sciences, 13(1), 41-58.

Camacho, C., Mariani, F. \& Pensieroso, L. (2017). Illegal immigration and the shadow economy. International Tax And Public Finance, 24(6), 1050-1080.

Çetinkaya, E. (2008). Türkiye'deki gençlerin kayıtdışı istihdamdaki durumu. Bilgi Dergisi, 2, 115-125.

Dam, M. M., Ertekin, Ş. ve Kızılca, N. (2018). Türkiye'de kayıt dışı istihdamın boyutu : Ekonometrik bir analiz. Dokuz Eylül Üniversitesi Iktisadi Ve İdari Bilimler Fakültesi Dergisi, 33(1), 293-318.

Danopoulos, C. P. \& Znidaric, B. (2007). Informal economy, tax evasion, and poverty in a democratic setting: Greece. Mediterranean Quarterly, 18(2), 67-84. 
Davidescu, A. A. A. (2015). The relationship between shadow economy and unemployment rate. A ardl causality analysis for the case of Romania. Romanian Statistical Review, 4. 46-62.

Dell'Anno, R. \& Solomon, O. H. (2008). Shadow economy and unemployment rate in USA: Is there a structural relationship? An empirical analysis. Applied Economics, 40, 2537-2555.

Dereli, T. (2007). Informal employment in Turkey. Sosyal Siyaset Konferansları, 53, 65-82.

Dobre, I. \& Alexandru, A. A. (2009). The impact of unemployment rate on the dimension of shadow economy in Spain: A structural equation approach. European Research Studies, 8(4), 179-197.

Elgin, C. (2012). Vergiler ve kayıtdışı ekonomi: Bir değerlendirme ve Türkiye örneği. ODTÜ Gelişme Dergisi, 39, 237-258.

Elijah, O. A. \& Uffort, L. (2007). Comparative analysis of the relationship between poverty and underground economy in the highly developed, transition and developing countries. MPRA Paper From University Library Of Munich, Germany, (2054).

Elveren, A. Y. \& Özgür, G. (2016). The effect of informal economy on income inequality: Evidence from Turkey. Panoeconomicus, 63(3), 293-312.

Ersöz, H. Y. (2004). Sosyal politika perspektifinden yerel yönetimler: Ingiltere, İsveç ve Türkiye örneği. İstanbul: Filiz Kitabevi.

Esenlikci, A. C. ve Engin, M. A. (2019). 1960'tan günümüze Avrupa Bïlï̆ï ülkelerïnde yaşayan Türk göçmenlerin sorunları. Hak Iş Uluslararası Emek ve Toplum Dergisi, 8(20), 59-77.

Espino, E. \& Sánchez, J. M. (2015). How does informal employment affect the design of unemployment insurance and employment protection? Federal Reserve Bank of St. Louis Review, 97(2), 159-172.

Firoozabadi, S. R., Razmi, M. J. \& Bahmani, M. N. D. (2015). Examining the effective social and economic factors on underground economy. Mediterranean Journal of Social Sciences, 6(3), $525-534$.

Fleming, M., Roman, J. \& Farrell, G. (2000). The shadow economy. Journal of International Affairs, 53(2), 387-409.

Gasteratos, J., Karamalis, M. \& Koutoupis, A. (2016). Shadow economy worsens income distribution. International Journal of Economics and Business Administration, 4(3), 80-92.

Georgiou, M. N. (2013). Income distribution and shadow economy. A worldwide panel data analysis. SSRN Electronic Journal, 1-10.

Güloğlu, T., Adem, K. ve Murat, K. (2003). Türkiye'de kayıtdışı istihdam gerçeğine bir bakış. Sosyal Siyaset Konferansları Dergisi, 45, 51-95.

ILO. (2018). Women and men in the informal economy: A statistical picture. Genava: International Labour Office.

Kaleli, E. ve Karaca, C. (2019). Türkiye'de kayıtdışı istihdama ilişkin çözüm önerileri. Sosyal Politika Çalışmaları Dergisi, 44, 769-792.

Kar, S. \& Saha, S. (2012). Corruption, shadow economy and income inequality: Evidence from Asia. IZA Discussion Papers, 7106. 
Karabacak, Y. (2013). Sosyal politika aracı olarak vergilemenin işlevleri: Türkiye örneği. İstanbul Üniversitesi iktisat Fakültesi Mecmuası, 62(2), 223-252.

Kırbaş, S. (2012). Türkiye'de kayıt dışı ekonomi, yolsuzluk, siyasetin finansmanı. Ankara: Phoenix Yayınevi.

Koray, M. (2018). Sosyal politika (5.bs). Ankara: İmge Kitabevi.

Mahiroğulları, A. (2017). Türkiye'de kayıtdışı istihdam ve önlemeye yönelik stratejiler. Süleyman Demirel Üniversitesi İktisadi ve İari Bilimler Fakültesi Dergisi, 22(2), 547-565.

Maroukis, T., Iglicka, K. \& Gmaj, K. (2011). Irregular migration and informal economy in Southern and Central Eastern Europe: Breaking the vicious cycle? International Migration, 49(5), 129-156.

Mauleón, I. \& Sardà, J. (2016). Unemployment and the shadow economy. Applied Economics, 49(37), 3729-3740.

Nacar Karabacak, B. (2013). Toplumsal dayanışmanın finansman boyutu: Türkiye'de sosyal politikaların finansmanı örneği. Çalışma ve Toplum, 2, 147-166.

Nikopour, H. \& Muzafar, S. H. (2010). Shadow economy and poverty. MPRA Paper. Münih.

Oktar, K. (2004). Kayıt dışı istihdam ve sosyal güvenlik. TBB Dergisi, 53, 266-270.

Önal, A. (2017). Türkiye'de devletin sosyal politikaları: sahici mi ve arka planı Ne? F. Taşçı (Ed.), Türkiye'de sosyal politika aktörleri: zemin ve uygulama içinde (ss. 1-32). Ankara: Nobel Yayın Dağıtım.

Önder, İ. (2001). Kayıtdışı ekonomi ve vergileme. İstanbul Üniversitesi Siyasal Bilgiler Fakültesi Dergisi, 23-24, 241-254.

Özdemir, S. (2007). Küreselleşme sürecinde refah devleti. İstanbul: İstanbul Ticaret Odası.

Öztürk, S. ve Başar, D. (2018). Türkiye'de kadınların işgücü piyasasına yönelik tercihleri: Kayıt dışı sektör özelinde bir analiz. Sosyal Güvenlik Dergisi, 8(2), 41-58.

Reyneri, E. (2003). Illegal immigration and the underground economy. National Europe Centre Paper. 68

Rosser, J. B., Rosser, M. V. \& Ahmed, E. (2000). Income inequality and the informal economy in transition economies. Journal of Comparative Economics, 28, 156-171.

Saafi, S., Mohamed, M. H. \& Farhat, A. (2015). Is There a causal relationship between unemployment and informal economy in Tunisia: Evidence from linear and non-linear granger causality. Economics Bulletin, 35(2), 1191-1204.

Sahnoun, M. \& Abdennadher, C. (2019). The nexus between unemployment rate and shadow economy: A comparative analysis of developed and developing countries using a simultaneousequation model. Economics Discussion Papers, 30.

Saraç, T. B. (2012). Kayıt Dışı ekonomi ve işsizlik ilişkisi: Türkiye örneği (2000/1-2011/2). Sosyoekonomi Dergisi, 8(18), 81-104.

Schneider, F. (2016). Estimating the size of the shadow economies of highly-developed countries: Selected new reults. 14, Münich. 
Smith, P. (1994). Assessing the size of the underground economy: The Canadian statistical perspectives. Canadian Economic Observer, 11, 16-33.

Sugözü, İ. H. (2010). Kayıt dışı ekonomi ve Türkiye. Ankara: Nobel Yayın Dağııım.

Talas, C. (1992). Türkiye'nin açıklamalı sosyal politika tarihi. Ankara: Bilgi Yayınevi.

Taşçı, F. (2017). Sosyal politika ahlakı. İstanbul: Kaknüs Yayınları.

Tekinarslan, M. (2014). Kayıtdışı istihdamla mücadele. Ankara: Türk Metal Yayınları.

Tuna, O. ve Yalçıntaş, N. (2011). Sosyal siyaset. İstanbul: Filiz Kitabevi.

Us, V. (2005). Kayıtdışı ekonomi. Iktisat İşletme ve Finans, 20(230), 95-109.

Williams, C. C. (2014). The informal economy and poverty: evidence And Policy Review. York: Joseph Rowntree Foundation.

Zaim, S. (1997). Çalışma ekonomisi (10.bs). İstanbul: Filiz Kitabevi 
